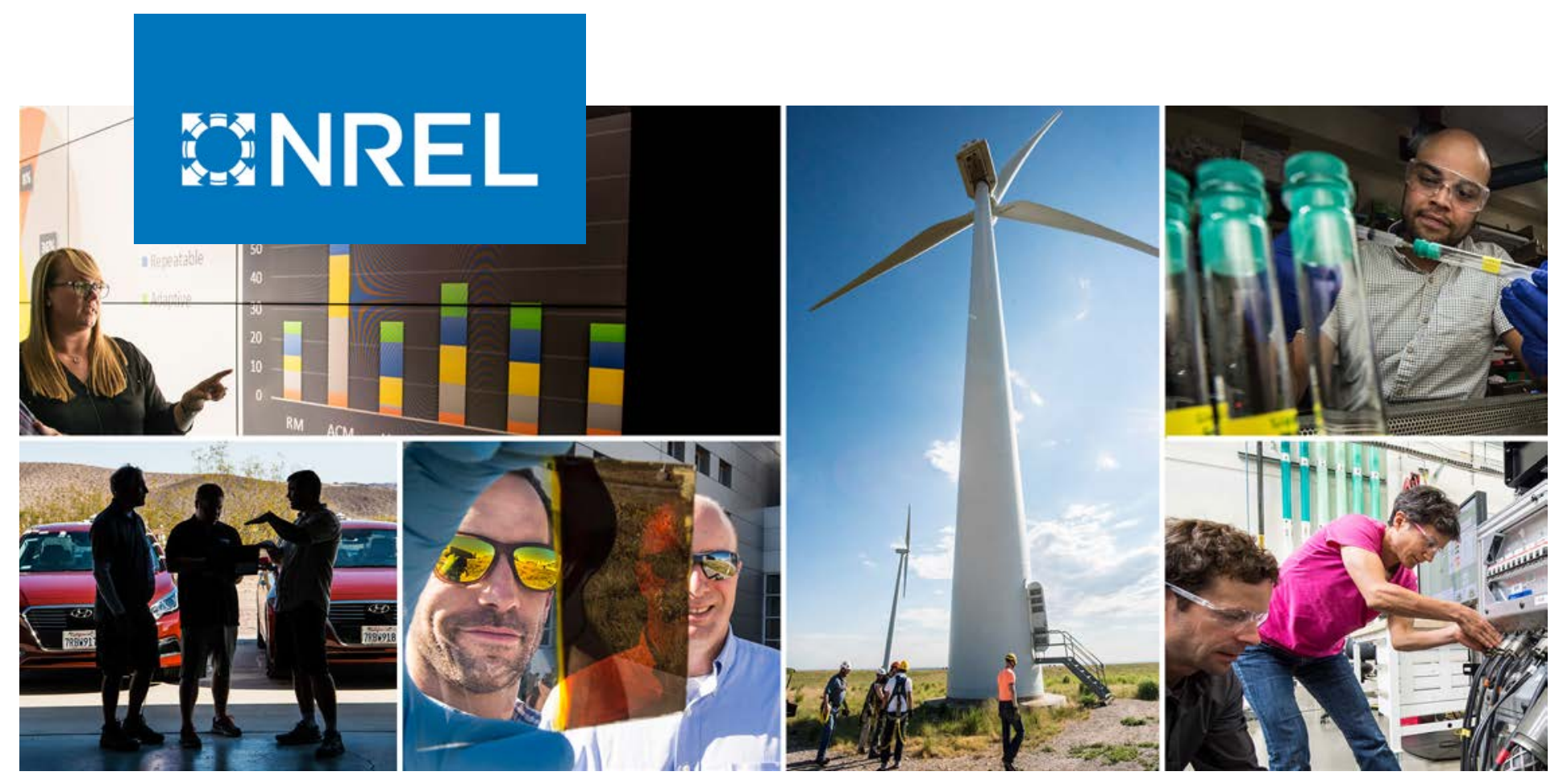

\title{
Initial Thermal Energy Yield Potential for the Use of Concentrating Solar Power (CSP) for Coal Hybridization in India
}

Parthiv Kurup ${ }^{1}$, Ted Kwasnik ${ }^{1}$, Billy Roberts ${ }^{1}$ and Tim Wendelin ${ }^{2}$

1 National Renewable Energy Laboratory (NREL)

2 Solar Dynamics

NREL is a national laboratory of the U.S. Department of Energy

Office of Energy Efficiency \& Renewable Energy

Operated by the Alliance for Sustainable Energy, LLC

This report is available at no cost from the National Renewable Energy Laboratory (NREL) at www.nrel.gov/publications.
Technical Report

NREL/TP- 6A20-74024

August 2019 


\section{GNREL}

\section{Initial Thermal Energy Yield Potential for the Use of Concentrating Solar Power (CSP) for Coal Hybridization in India}

Parthiv Kurup ${ }^{1}$, Ted Kwasnik ${ }^{1}$, Billy Roberts ${ }^{1}$ and Tim Wendelin ${ }^{2}$

1 National Renewable Energy Laboratory (NREL)

2 Solar Dynamics

\section{Suggested Citation}

Kurup, Parthiv, Ted Kwasnik, Billy Roberts and Tim Wendelin. 2019. Initial Thermal Energy Yield Potential for the Use of Concentrating Solar Power (CSP) for Coal Hybridization in India. Golden, CO: National Renewable Energy Laboratory. NREL/TP-6A20-74024.

https://www.nrel.gov/docs/fy19osti/74024.pdf.

NREL is a national laboratory of the U.S. Department of Energy Office of Energy Efficiency \& Renewable Energy Operated by the Alliance for Sustainable Energy, LLC

This report is available at no cost from the National Renewable Energy Laboratory (NREL) at www.nrel.gov/publications.

Contract No. DE-AC36-08GO28308
Technical Report

NREL/TP- 6A20-74024

August 2019

National Renewable Energy Laboratory 15013 Denver West Parkway Golden, CO 80401

303-275-3000 • www.nrel.gov 


\section{NOTICE}

This work was authored by the National Renewable Energy Laboratory, operated by Alliance for Sustainable Energy, LLC, for the U.S. Department of Energy (DOE) under Contract No. DE-AC3608GO28308. Funding provided by the U.S. Department of Energy Office of Science, Basic Energy Sciences program; by the U.S. Department of Energy Office of Energy Efficiency and Renewable Energy, Solar Energy Technologies Office; and by the U.S. Department of Energy, Office of International Affairs. This research is based upon work supported by the Solar Energy Research Institute for India and was also jointly funded by the Government of India subcontract IUSSTF/JCERDC-SERIIUS/2012 dated 22nd Nov. 2012. The views expressed in the article do not necessarily represent the views of the DOE or the U.S. Government.

This report is available at no cost from the National Renewable Energy Laboratory (NREL) at www.nrel.gov/publications.

U.S. Department of Energy (DOE) reports produced after 1991 and a growing number of pre-1991 documents are available free via www.OSTI.gov.

Cover Photos by Dennis Schroeder: (clockwise, left to right) NREL 51934, NREL 45897, NREL 42160, NREL 45891, NREL 48097, NREL 46526.

NREL prints on paper that contains recycled content. 


\section{Acknowledgments}

The authors would like to thank Ravi Kumar at the Indian Institute of Technology in Delhi and Elina Hakkarainen, Matti Tähtinen, and Janne Kärki from the Technical Research Centre of Finland (VTT), who supported this analysis with knowledge and insight. Special thanks also to Tim Wendelin, the original concentrating solar power (CSP) lead on Phase 1 of the Solar Energy Research Institute for the India and U.S. (SERIIUS) endeavor, and David Ginley, the overall National Renewable Energy Laboratory (NREL) program manager for the SERIIUS Phase 1 efforts. 


\begin{tabular}{|c|c|}
\hline $\mathrm{C}$ & Celsius \\
\hline CSP & concentrating solar power \\
\hline DLR & $\begin{array}{l}\text { German Aerospace Center (German: Deutsches Zentrum für Luft- und } \\
\text { Raumfahrt) }\end{array}$ \\
\hline DNI & direct normal irradiance \\
\hline DSG & direct steam generation \\
\hline GADM & Database of Global Administrative Areas \\
\hline GIS & geographic information system \\
\hline $\mathrm{GW}_{\mathrm{e}}$ & gigawatt-electric \\
\hline $\mathrm{GWh}_{\text {th }}$ & gigawatt-hour thermal \\
\hline HTF & heat transfer fluid \\
\hline HP & high-pressure \\
\hline INR & Indian Rupees \\
\hline ISCC & integrated solar combined cycle \\
\hline $\mathrm{km}$ & kilometers \\
\hline $\mathrm{km}^{2}$ & kilometers squared \\
\hline $\mathrm{kWh} / \mathrm{m}^{2} /$ day & kilowatt-hours per meter squared per day \\
\hline $\mathrm{kWh} / \mathrm{m}^{2} / \mathrm{yr}$ & kilowatt-hours per meter squared per year \\
\hline LF & linear Fresnel \\
\hline $\mathrm{m}$ & meters \\
\hline M & million \\
\hline $\mathrm{MW}_{\mathrm{e}}$ & megawatt electric \\
\hline $\mathrm{MW}_{\text {th }}$ & megawatt thermal \\
\hline$M W h_{\text {th }}$ & megawatt-hours thermal \\
\hline NASA & National Aeronautics and Space Administration \\
\hline NREL & National Renewable Energy Laboratory \\
\hline NTPC & National Thermal Power Corporation Limited \\
\hline NSRDB & National Solar Radiation Database \\
\hline PV & photovoltaic \\
\hline RPO & renewable purchase obligations \\
\hline SERIIUS & Solar Energy Research Institute for India and U.S. \\
\hline SF & solar field \\
\hline TES & thermal energy storage \\
\hline $\mathrm{TW}_{\text {th }}$ & terawatts thermal \\
\hline TWh & terawatt-hours \\
\hline $\mathrm{TWh}_{\mathrm{th}}$ & terawatt-hours thermal \\
\hline USD & United States dollars \\
\hline USGS & United States Geological Survey \\
\hline VRE & variable renewable energy \\
\hline VTT & Technical Research Center of Finland \\
\hline
\end{tabular}




\section{Executive Summary}

The hybridization of concentrating solar power (CSP) with coal-based power generation may serve to mitigate fossil fuel use externalities, increase energy security, and allow older coal plants to meet current and future government emissions regulations. This report (focused on India), provides a Geographic Information System (GIS)-based methodology for assessing the country's technical potential for CSP hybridization with coal-based power, considering solar resource, land and siting constraints, and the location of existing coal power plants. Presently, one CSP-coal hybrid exists in India.

We first estimate 633,000 terawatts thermal $\left(\mathrm{TW}_{\text {th }}\right.$ ) annually to be the upper bound on thermal energy production from parabolic trough systems (without storage) in India before technical constraints are applied. Next, we consider land characteristic constraints, contiguous solar field (SF) area limitations, and existing coal plant proximity. Accordingly, we refine the potential for CSP hybridization in India to a technical upper limit of 103,000 gigawatt-hours thermal $\left(\mathrm{GWh}_{\mathrm{th}}\right)$. This subsequent estimate reflects the potential output of new 25-megawatt thermal ( $\left.\mathrm{MW}_{\text {th }}\right) \mathrm{CSP}$ SFs within 1,000 meters $(\mathrm{m})$ of coal plants where solar resource - that is, the direct normal irradiance (DNI) - is more than $4.0 \mathrm{kWh} / \mathrm{m}^{2} /$ day. The average capacity factor of these CSP SFs in suitable areas is expected to be $21.1 \%$ on average. While only about $10 \%$ of the land with suitable solar resources within $1,000 \mathrm{~m}$ of existing coal plants is anticipated to be viable for hybridization development, we estimate a 43-MW th SF could be used for each viable coal plant, yielding $81 \mathrm{GWh}_{\text {th }}$ annually on average.

At a regional level, we provide state and regional territory summary statistics regarding coal power plant development, solar resource, and CSP-coal hybridization in India. We find Andhra Pradesh, Chhattisgarh, and Tamil Nadu are particularly suited to CSP hybridization, as the abundance of suitable land in these states near existing coal plants would allow SFs to provide more than $130 \mathrm{GWh}_{\text {th }}$ annually on average to each coal plant in these regions. Our results also illustrate that in places like Gujarat relatively high solar resource can be offset by siting constraints.

This high-level analysis is intended as a preliminary estimate to be further refined with timeseries data of solar resource and coal power plant operations. Moreover, the cumulative economic potential is expected to be less than the technical potential, given spatial variability in costs and the value of energy produced. Future research will be needed to assess the financial viability of hybridization, categorize the potential by CSP technologies (e.g., parabolic trough, linear Fresnel [LF], and CSP-coal hybridization, combined with thermal energy storage [TES]) and heat hybridization strategies (e.g., boiler feedwater heating, and, potentially, coal drying).

This study shows significant CSP-coal hybridization potential for the existing coal plants in India. This preliminary study suggests CSP-coal hybridization may play a supporting role in India's developing energy system. The methodology could also be adapted for other areas of the world, such as the United States. 


\section{Table of Contents}

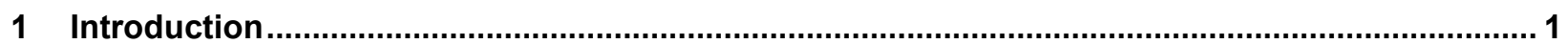

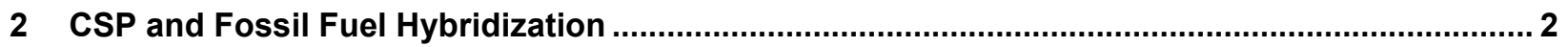

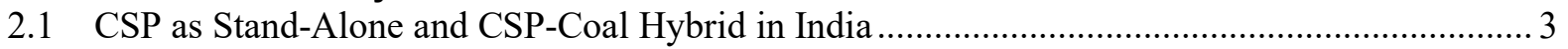

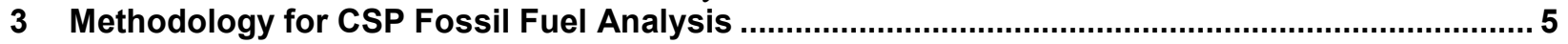

3.1 Calculating CSP Thermal Energy Resource Potential ............................................................. 5

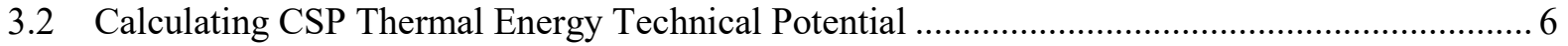

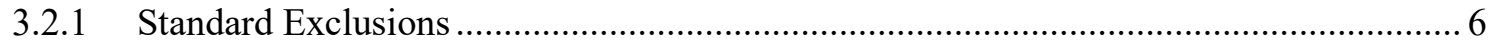

3.2.2 Plant Size and Existing Coal Plant Proximity Exclusions ........................................... 7

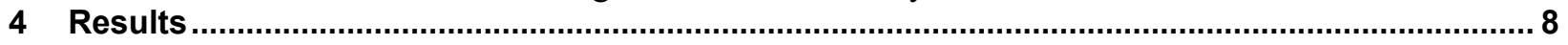

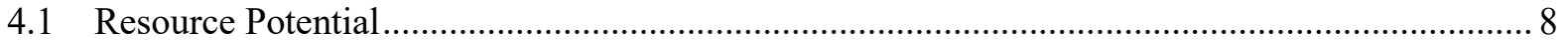

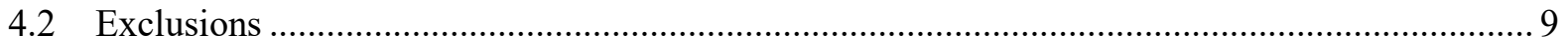

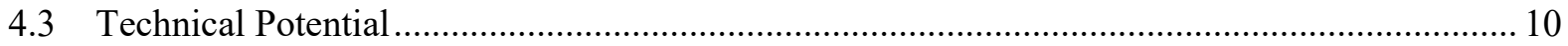

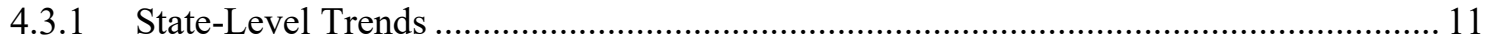

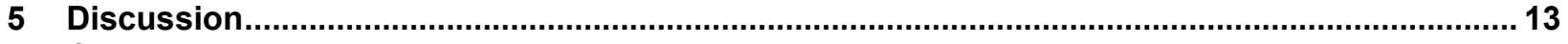

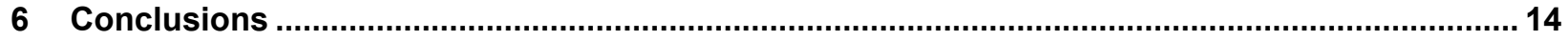

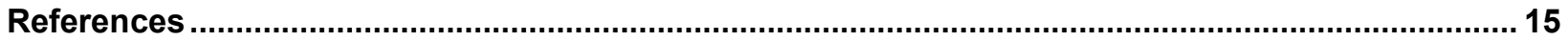

Appendix A. Land Use and Cover Classification Exclusions ................................................... 18

Appendix B. State Resource Potential and Exclusion Statistics ............................................... 19

Appendix C. Average Site Technical Potential, Land Suitability, and Capacity Factors by State 21 


\section{List of Figures}

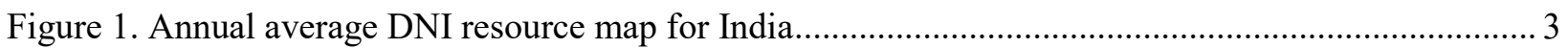

Figure 2. CSP-coal hybridization at one unit of the Dadri Power plant.................................................. 4

Figure 3. Annual generation potential for CSP-coal hybridization by state and union territories ................ 8

Figure 4. Coal plants and annual thermal energy production $\left(\mathrm{MWh}_{\mathrm{th}}\right)$ in suitable India locations ............ 10

\section{List of Tables}

Table 1. DNI to CSP Capacity Factor............................................................................................... 5

Table 2. Technical Potential and Suitable Land Area by Coal Plant Proximity and CSP Project Size ...... 11

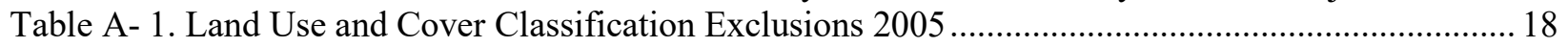

Table B- 1. State Resource Potential and Exclusion Statistics ............................................................ 19

Table C- 1. Average Technical Potential, Land Suitability, and Capacity Factors by State....................... 21 


\section{Introduction}

The Indian energy sector is dominated by fossil fuels and thermal generation, particularly coal. As of 2018, coal made up approximately $57 \%$ of India's gross generation capacity (approximately 200 gigawatt-electric $\left[\mathrm{GW}_{\mathrm{e}}\right]$ ), with about $80 \%$ of India's coal consumption for electricity generation (Tongia and Gross 2019$)$. The 2018 coal capacity in India $\left(200 \mathrm{GW}_{\mathrm{e}}\right)$ is expected to rise to $234 \mathrm{GW}_{\mathrm{e}}$ by 2022 through projects in construction (Palchak et al. 2017).

Coal plants in India tend to be designed for domestic subcritical coal. This lower-quality coal, while affordable, poses efficiency and environmental concerns; its low energy value results in burning more coal to achieve energy output equivalent to higher-quality alternatives, contributing to elevated rates of greenhouse gas emissions (Penney and Cronshaw 2015). And although India is the third largest global producer of coal (Economic Times of India 2017), reliance on foreign coal imports has been increasing, as domestic production cannot keep up with demand (EIA 2014; Economic Times of India 2017). As of 2017, India imported approximately 190 million (M) tons of coal (Economic Times of India 2017).

Nonetheless, India is capable of fundamentally supporting a transition to a cleaner, more robust, renewable energy system that benefits the economic and physical health of its population (Palchak et al. 2017). Recent studies have indicated that wind and photovoltaic (PV) in India could reach installed capacities of $60 \mathrm{GW}_{\mathrm{e}}$ and $100 \mathrm{GW}_{\mathrm{e}}$, respectively, by 2022 (Palchak et al. 2017). With increased variable renewable energy (VRE) penetrations (e.g., from wind and PV), large grids have been found to benefit from the addition of concentrating solar power (CSP) and thermal energy storage (TES) (Mehos et al. 2016). As noted by Palchak et al., the significantly increased wind and PV capacity expansion in the Indian grids would typically decrease coal plant load factors, leading to increased fuel use, costs, and emissions, per unit of generation (Palchak et al. 2017). The hybridization of CSP with coal-based electricity generation plants provides one approach to improving existing coal plant operations, improving grid flexibility, and reducing the wind and PV curtailment seen in high-VRE penetrations (Palchak et al. 2017). Steam and heat derived from CSP, for example, can be used to decrease domestic and imported coal usage and allow older coal plants to meet current and future government emissions regulations as regulations change.

In this report, we investigate the technical potential for CSP solar fields (SFs) to supply heat to existing coal power plants. Though multiple CSP technologies exist, and CSP-derived heat is also applicable to natural gas power plants (Turchi and Langle 2011), we chose to limit this preliminary study to the utilization of parabolic troughs with oil-heat transfer fluid (HTF) operating at $393^{\circ}$ Celsius (C) without TES to the hybridization of existing coal plants. The report provides a methodology for determining the technical thermal energy yield potential for such hybrid systems by assessing both the theoretical resource potential and technical potential, with land suitability and proximity to coal power plant constraints applied. Section 2 briefly highlights other work in the field of CSP-fossil fuel hybridization. Section 3 highlights the new methodology developed to geographically constrain and assess technical potential for CSP hybridization. Sections 4, 5, and 6 provide results, a discussion, and conclusions, respectively. Supplemental appendices (A, B, and C) provide derived resource assessments and the thermal energy yield potential at the national and state levels for India. 


\section{CSP and Fossil Fuel Hybridization}

The most prominent CSP technologies used for CSP-fossil fuel hybridization are the parabolic trough and linear Fresnel (LF), which are forms of mirrored solar collectors. While direct steam generation (DSG) in the SF can be produced either in parabolic troughs or LF systems (Kurup and Turchi 2015), this study does not consider DSG or LF. CSP requires good direct normal irradiance (DNI), land availability, and a well-developed supply chain (e.g., local manufacturing of key components) to help ensure the investment costs are competitive to other technologies (Kulichenko et al. 2014). CSP SFs can be implemented as stand-alone electricity generators, added to existing coal and natural gas facilities to provide heat input, or used in enhanced oil recovery (Deshmukh et al. 2019). For stand-alone electricity generation plants to be economically feasible from CSP, DNI greater than 2,000 kilowatt-hours per square meter per year $\left(\mathrm{kWh} / \mathrm{m}^{2} / \mathrm{yr}\right.$ ) was found suitable (IRENA 2012) - less DNI is required for integrated SFs for hybridization (NTPC 2016). Note the capital cost requirements are much lower for CSP hybrid systems than stand-alone CSP electricity generation plants, due to lower equipment costs and the ability to integrate with existing power generation equipment (Deshmukh et al. 2019) (e.g., the power block is already present in the coal power plant). In fact, Deshmukh et al. find that CSP integration with coal plants may reduce operating costs by $18 \%$, while also increasing power output by $25 \%$ (Deshmukh et al. 2019).

When used as an integrated solar combined cycle (ISCC), CSP SFs provide heat or steam to fossil fuel plants in support of multiple functions. For example, heat and steam may be inputs for the feedwater preheat or accomplish cold line reheat after the high-pressure (HP) steam turbine. Solar steam may also be directly sent to the HP turbine (Hakkarainen et al. 2017). Ultimately, the heat and steam generated by the SF provides flexibility to fossil fuel plants, enabling them to decrease the fuel use at the coal plant (i.e., fuel saving mode), or to increase the power output of an underused steam turbine (i.e., power boost mode) (Hakkarainen et al. 2017).

Research and development organizations, as well as commercial companies, have laid a strong foundation for understanding the potential for the hybridization of CSP technologies with coal and natural gas plants. The National Renewable Energy Laboratory (NREL), for example, has undertaken solar-augmentation potential studies for U.S. coal and natural gas plants, showing the capacity potential for $11 \mathrm{GW}_{\mathrm{e}}$ of parabolic trough hybridization and $13 \mathrm{GW}_{\mathrm{e}}$ of power tower CSP hybridization potential (Turchi and Langle 2011). A version of coal hybridization with CSP technology is the research ongoing by the German Aerospace Center (DLR) to use molten-salt TES tanks at the coal plant, absorb VRE from sources like excess wind and PV from the grid, then store heat and generate steam, which can be fed into the existing coal plant (Deign 2019). The feasibility study is underway (Deign 2019), and hybridization construction could begin in 2020 (RWE Power AG 2019). This could also be an option in India.

Forays into CSP hybridization find that viable and high-potential markets exist in China, India, and the United States (Schuknecht, Kulbeik, and O'Rourke 2017; Turchi and Langle 2011). As of this report's writing, however, few concrete demonstrations of CSP SFs provide heat input for coal power plants. Across the world, only five parabolic trough SFs without TES are hybridized with ISCC plants, constituting approximately $104 \mathrm{MW}_{\mathrm{e}}$, that are either in operation, development or construction (NREL and SolarPACES 2017). The parabolic trough using oil-HTF and without TES was therefore chosen to be representative for this study. 
Looking to the future and beyond this study, the Technical Research Center of Finland (VTT) is refining analysis of integration challenges and optimal CSP technology choices at suitable coal sites (Hakkarainen et al. 2017), and these types of strategies are already being implemented at sites like the CSP-coal hybrid at the Dadri coal power plant in India (NTPC 2016).

\subsection{CSP as Stand-Alone and CSP-Coal Hybrid in India}

Figure 1 reveals that India generally receives DNI at the low range of suitability for CSP standalone electricity generation. Large swaths of the country's northern regions fall below 4.0 kilowatt-hours per meter squared per day ( $\mathrm{kWh} / \mathrm{m}^{2} /$ day). Aerosols and dust pollution further reduce resource availability, and the DNI is consistently greater than or equal to 2,000 $\mathrm{kWh} / \mathrm{m}^{2} / \mathrm{yr}$ in only a few regions (e.g., the Thar Desert in Rajasthan, which is approximately 5.0 $\mathrm{kWh} / \mathrm{m}^{2} /$ day, as labeled in Figure 1). Advantageously, to hybridize coal power plants with CSP SFs, much less DNI is needed than for stand-alone electricity generation (NTPC 2016).

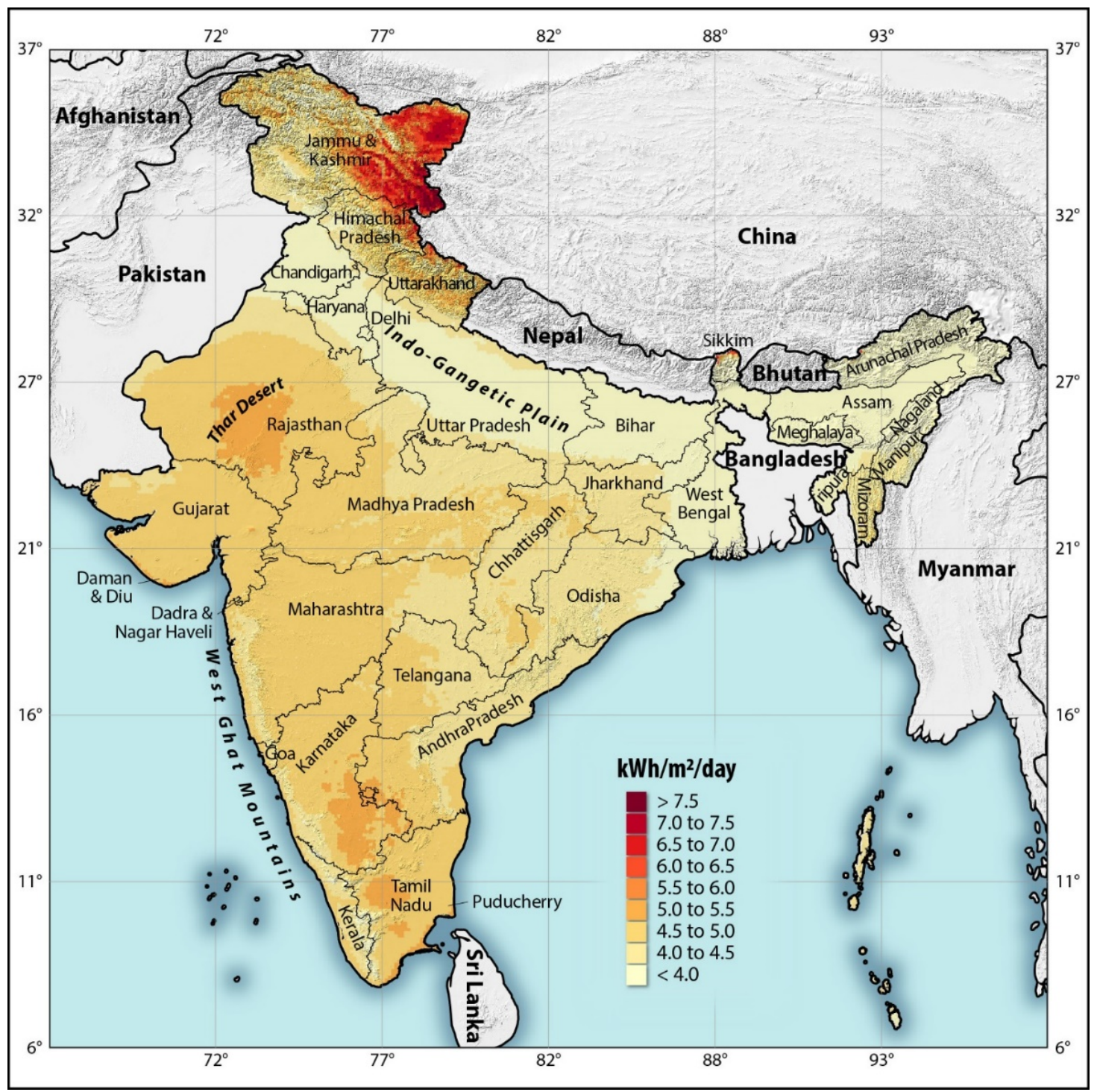

Figure 1. Annual average DNI resource map for India

Image by Billy Roberts 
The Indian government provides numerous incentives for the development of solar energy technologies, including low-interest loans, Renewable Purchase Obligations (RPO), the declaration of renewable zones, tax exemptions, and direct subsidies (Deshmukh et al. 2019). Under the Indian government's Jawaharlal Nehru National Solar Mission initiative, a goal was established to construct $470 \mathrm{MW}_{\text {e }}$ of new CSP plants from 2011-2013, such that this additional capacity was operational by 2014 (Choudhury 2013). Even in 2016, however, less than half of this electricity generation capacity was realized (at best), and some projects were still in construction (Bijarniya, Sudhakar, and Baredar 2016). As such, the Indian CSP market for pure electricity generation is still developing. It is important to highlight that Coal India Limited, one of the largest coal producers in India, has been mandated to become a net-zero energy company by the Indian Ministry of Coal, where CSP is a viable technology in decreasing coal usage in the 2,000-MW portfolio (CSP Focus 2018).

The first and only CSP-coal hybridization in India has been proposed by Frenell, a German company. Frenell won a contract to deploy the LF technology, hybridize the Dadri coal plant in Uttar Pradesh, India, and potentially supply $14 \mathrm{GWh}_{\text {th }}$ of thermal energy into the water-steam cycle (CSP Today 2016; Hasem 2017). The 28-acre, 15-MW th $\mathrm{SF}$ is expected to generate steam for one of the 210-MW steam turbines (NTPC 2016). An operational schematic of how the LF SF would integrate with the existing steam turbine is shown in Figure 2. The pressurized water or steam exits the SF at $280^{\circ} \mathrm{C}$ at 65 bar, feeding the solar heat exchanger, which then provides $247^{\circ} \mathrm{C}$ steam after the high-pressure heater that supplies steam to the steam turbine (NTPC 2016).

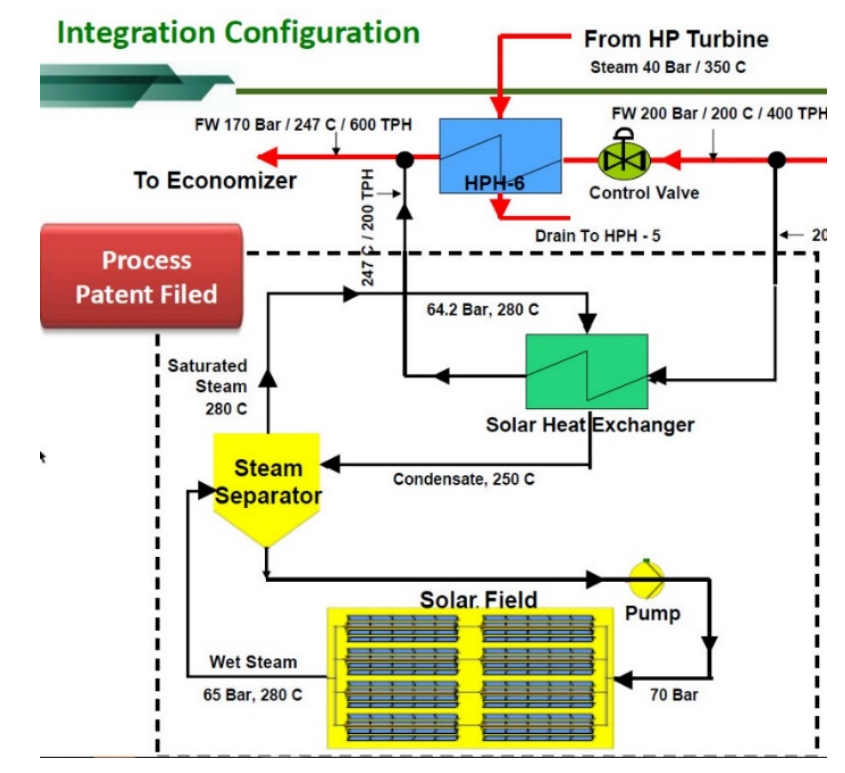

Figure 2. CSP-coal hybridization at one unit of the Dadri Power plant

Image from NTPC 2016

National Thermal Power Corporation Limited (NTPC) report that the 15-MW th SF without TES would lower the startup time of the steam turbine, increase the energy generated, and do so at low capital cost for the hybridization (NTPC 2016). The estimated project cost was 69 Crore or 690 M Indian Rupees (INR) (NTPC 2016), which in 2016 was approximately \$10.2 M U.S. dollars (USD) (X-Rates 2019). 


\section{Methodology for CSP Fossil Fuel Analysis}

This assessment of CSP hybridization potential first translates solar resource into estimates of annual thermal energy production. Subsequently, areas identified as being offshore, of a land use type that inhibits development, high slope, conflicting with environmentally sensitive areas, or beyond a set distance to major roads, are excluded from analysis. Finally, contiguous land area constraints by SF size are applied, and remaining areas are summarized by proximity to existing coal plants. The method assumes greenfield sites where new SFs could be built. The following section describes the data and assumptions behind these steps in greater detail.

\subsection{Calculating CSP Thermal Energy Resource Potential}

The resource potential of CSP-derived thermal energy represents an upper bound on the annual thermal energy that can theoretically be produced in India. It is derived from DNI data through calculations of capacity factor and annual thermal energy production.

The National Solar Radiation Database (NSRDB) (NREL 2014), covering 2000-2014 at a 0.1 by 0.1 degree spatial resolution (i.e. 10 kilometers $[\mathrm{km}]$ x $10 \mathrm{~km}$ resolution) provides a multiyear mean for hourly DNI measured in $\mathrm{kWh} / \mathrm{m}^{2} /$ day. This data set was developed by NREL in cooperation with India's Ministry of New and Renewable Energy. ${ }^{1}$

In this analysis, each pixel in the solar DNI resource data set is reclassified into a capacity factor, such that values below $4.0 \mathrm{kWh} / \mathrm{m}^{2} /$ day reflected $0 \%$, those above $6.0 \mathrm{kWh} / \mathrm{m}^{2} /$ day reflected $25 \%$, and values between these thresholds were linearly scaled from $20 \%-25 \%$. This scheme, summarized in Table 1, is meant to reflect that solar resource less than $4.0 \mathrm{kWh} / \mathrm{m}^{2} /$ day is typically not economical for CSP project development. Moreover, capacity factors for parabolic troughs without storage typically range from 20-25\% (IRENA 2012).

Table 1. DNI to CSP Capacity Factor

\begin{tabular}{ll}
\hline DNI Range & Capacity Factor $\left(\mathbf{k W h} / \mathbf{m}^{2} /\right.$ day $)$ \\
\hline $0<\mathrm{DNI}<4$ & 0 \\
$4<=\mathrm{DNI}<=6$ & $20+(5 \times(\mathrm{DNI}-4.0) / 2.0)$ \\
$\mathrm{DNI}>6$ & 25 \\
\hline
\end{tabular}

Next, capacity factors at each pixel are translated into an estimated annual thermal energy yield, in megawatt-hour thermal $\left(\mathrm{MWh}_{\mathrm{th}}\right)$. This calculation, reproduced below, builds on a previous NREL work (Kurup and Turchi 2015; Lopez et al. 2012), assuming a parabolic trough (without storage) has a thermal power density of $139.3 \mathrm{MWth} / \mathrm{km} 2$, as follows in Equation 1:

MW Thermal per pixel

$$
\begin{aligned}
& =0.0081 \mathrm{~km} 2 \times 139.3 \mathrm{MWth} / \mathrm{km} 2 \\
& \times \text { Capacity Factor }(\% \text { of } 8760) \times 8760 \text { hours per year }
\end{aligned}
$$

\footnotetext{
${ }^{1}$ Download instructions for this data set are available at https://nsrdb.nrel.gov/download-instructions.
} 


\subsection{Calculating CSP Thermal Energy Technical Potential}

The technical potential for CSP thermal energy refines the resource potential by excluding areas that are not suitable for CSP development. This analysis includes the static exclusions (Section 3.2.1) and subsequent variable plant size and coal plant proximity exclusions (Section 3.2.2).

\subsubsection{Standard Exclusions}

This analysis of CSP-coal hybridization potential in India makes use of political boundary, road, coal plant, environmentally sensitive areas, elevation, land use, and cover spatial data sets to exclude potential sites for development. All data sets are initially translated from their native format into a raster file with a common projection, extent, and resolution - in this case, to the Asia South Albers Equal Area Conic (WKID 10208) projection, a 90-m spatial resolution, and a bounding box extending beyond the borders of India.

Areas designated as unsuitable for development, detailed in the following sections, are excluded from the annual thermal production layer calculated in Section 3.1. Figure 3 in Section 4.2 illustrates the cumulative areas of exclusion, as applied to the national estimates of CSP annual thermal energy production.

\section{India Boundaries}

The Database of Global Administrative Areas (GADM), which contains the spatial database of world administrative areas, provided the boundaries of India (GADM 2018). Only areas over land are included in this analysis.

\section{Roads}

Roads, as recorded in the OpenStreetMap project at the time of analysis (Geofabrik 2018), are used to estimate site suitability. Those areas surrounding the coal plant and farther than $10 \mathrm{~km}$ from major roads are excluded from analysis, as it may be costly and difficult to get SF components to the coal power plant.

\section{Environmentally Sensitive Areas}

Areas excluded from analysis include areas designated in the World Database on Protected Areas Consortium (ProtectedPlanet 2018). This data set includes all classifications of protected areas as defined by the International Union for Conservation of Nature, as well as other protected areas defined under international agreements.

\section{Slope}

Areas also excluded include areas with a slope greater than 3\%, as modeled in the United States Geological Survey (USGS) GTOPO30 data set (USGS 1993), which is available at 30-arc second resolution.

\section{Land Use and Land Cover}

The National Aeronautics and Space Administration (NASA) Decadal Land Use and Land Cover Classification for 2005 provided land-use types (NASA 2016). This data set is derived from data provided by the Indian Space Research Organization and Landsat from the USGS and comes at a 100-m resolution. Appendix A provides a summary of classification types and whether each was excluded from potential CSP hybridization development. 


\subsubsection{Plant Size and Existing Coal Plant Proximity Exclusions}

The India Coal Power Plants Database (KAPSARC 2018) supplied the location, type, size, and status of coal generation facilities used in this analysis - those plants with status designations of retired, shelved, decommissioned, and canceled were excluded from analysis.

This analysis assumed that contiguous land is needed to build SFs that integrate with existing coal power plants, and that land can be expected to generate a thermal yield based on the DNI and capacity factor. Accordingly, the resource potential (Section 3.1) constrained by standard exclusions (Section 3.2) was filtered by each of three minimum contiguous land area limitations based on three modeled CSP SF sizes: 25,50 , and $100 \mathrm{MW}_{\text {th. }}$. At an assumed thermal energy density of $139.3 \mathrm{MW}_{\mathrm{th}} / \mathrm{km}^{2}$ (Kurup and Turchi 2015; Lopez et al. 2012), minimum contiguous land-area filters are calibrated to $0.18,0.36$, and $0.72 \mathrm{~km}^{2}$ (i.e., the land needed to build $25-, 50$-, and $100-\mathrm{MW}_{\text {th }} \mathrm{SFs}$ adjacent to the existing coal power plant).

Finally, proximity thresholds of 250,500 , and $1,000 \mathrm{~m}$ were applied to each filtering result by contiguous area. The intent of limiting the distance of the CSP SF from the coal power plant was to reflect the difficulty of transmitting heat effectively over large distances and developing pipelines to bring heat from the solar field to the coal power plant. Future analysis will look to more accurately model system configuration parameters and heat losses. 


\section{Results}

The following sections describe the results from the full resource potential for CSP-coal hybridization in India, the exclusion of unsuitable areas, and the technical potential by proximity to existing coal plants and proposed CSP SF size.

\subsection{Resource Potential}

The average DNI in India is approximately $4.4 \mathrm{kWh} / \mathrm{m}^{2} /$ day, cumulatively accounting for more than 13,780 terawatt hours (TWh) each day. Without taking land-based exclusions into account, this solar resource translates into the potential for 633,000 terawatt hours thermal $\left(\mathrm{TWh}_{\mathrm{th}}\right)$ of thermal energy generation annually. Both Figure 1, which illustrates the average DNI across the country, and Appendix B, which provides a breakdown of resource potential by state, reveal the areas in India with the solar resource most suitable to CSP development are in the northeast and south. Figure 3 shows the breakdown of the generation potential by state and union territories, as found in Appendix B.

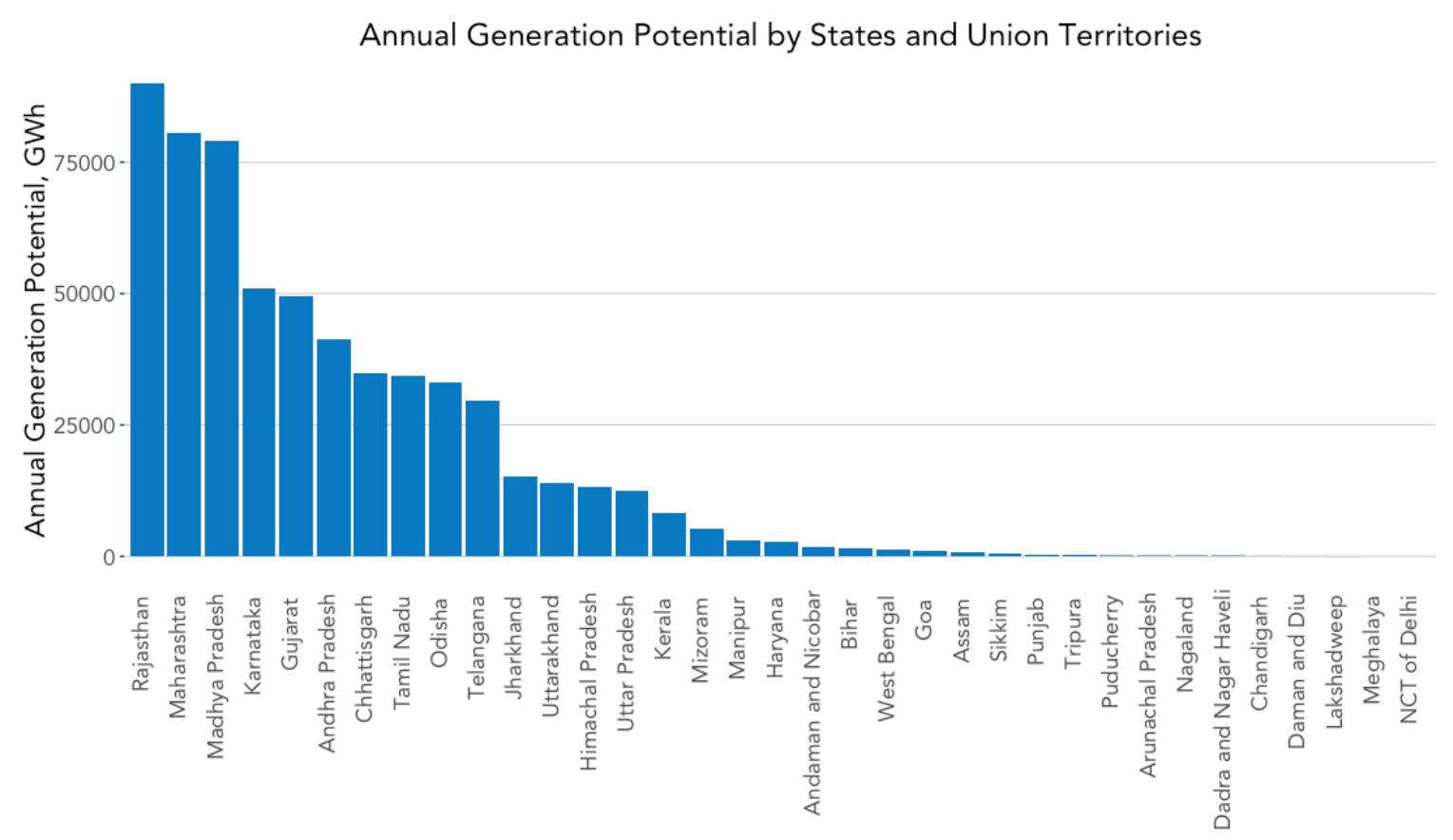

Figure 3. Annual generation potential for CSP-coal hybridization by state and union territories

For example, the northeastern states of Rajasthan and Gujarat, as well as the southern states of Karnataka, Tamil Nadu, and western portions of Andhra Pradesh, have average DNI values that exceed $5.0 \mathrm{kWh} / \mathrm{m}^{2} /$ day. Solar resource is strong in Jammu, Kashmir, Daman, Diu, Lakshadweep, and Puducherry, yet small cumulative land areas and few prospects for coal hybridization render these states less suited to the interests of this report.

The least suitable locations for development - locations receiving less than $4.0 \mathrm{kWh} / \mathrm{m}^{2} /$ dayare generally along India's western coast and a northwestern band hundreds of kilometers wide running along the Indo-Gangetic Plains south of the Himalayas. The Western Ghat mountains in Kerala are also ill-suited to CSP hybridization development. 


\subsection{Exclusions}

Exclusions restrict development across $44 \%$ of India's land area and 54\% of areas that receive an average $4.0 \mathrm{kWh} / \mathrm{m}^{2} /$ day or more. Land use is the single greatest exclusionary factor, reducing overall suitable land by $28 \%$. Slope is the second most prominent factor, rendering $20 \%$ of India's land unsuitable for CSP development. In this analysis, $14 \%$ of land is excluded due to distance from major roads, $5 \%$ due to environmentally sensitive areas, and $3 \%$ due to the presence of urban areas. Tamil Nadu, Karnataka, Gujarat, and Rajasthan emerge as highly constrained states but with strong solar resource, as the average DNI is above $4.7 \mathrm{kWh} / \mathrm{m}^{2} /$ day; however, suitability is constrained in two-thirds or more of the land area. Chhattisgarh is notable for its strong resource and below-average excluded area. Other state summaries can be found in Appendix B.

Figure 4 illustrates where coal plant proximity to adequate CSP thermal generation potential and site suitability exclusions are expected to inhibit CSP-coal hybridization development. Across India, we consider 1,265 coal plants that on average have $366 \mathrm{MW}_{\mathrm{e}}$ of average system capacity and tend to be in the central to western parts of the country.

Chhattisgarh, Maharashtra, Orissa, Tamil Nadu, and Uttar Pradesh are the most prolific coal states, each containing more than 100 generation sites. At $250 \mathrm{~m}$ from coal plants, about twothirds of sites have no access to suitable land, and increasing the proximity radius to $1,000 \mathrm{~m}$ brings the proportion of sites with access to suitable land to slightly more than half. Moreover, about $90 \%$ of all potential land within $1,000 \mathrm{~m}$ of a coal plants is unsuitable for development. Excluding sites without access to at least some adequate solar resource, $83 \%$ of land within $1,000 \mathrm{~m}$ is suitable.

In Figure 4, coal plants are unsuitable for CSP-coal hybridization if no land within 1,000 $\mathrm{m}$ is estimated to support CSP SF requirements. 


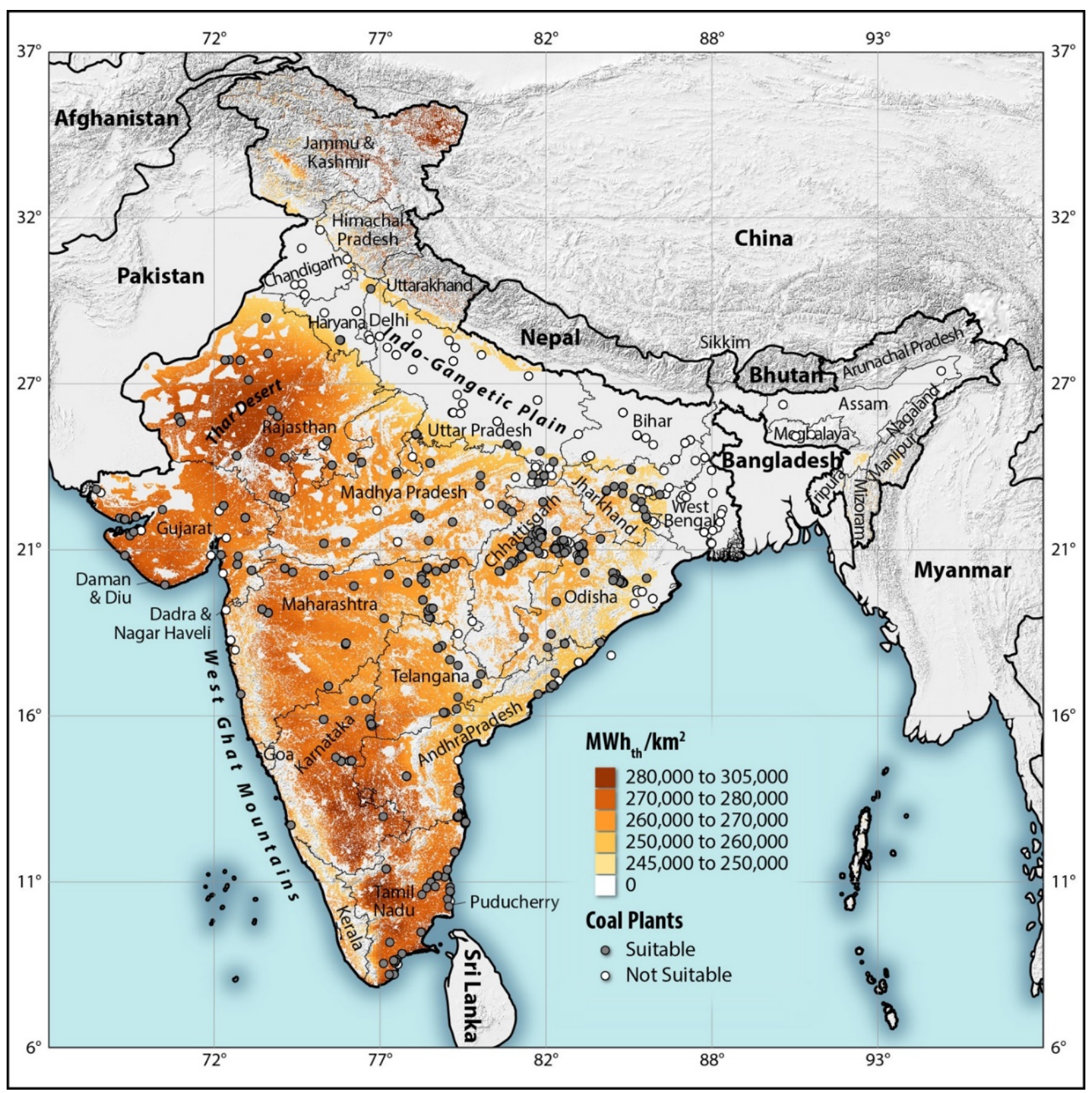

Figure 4. Coal plants and annual thermal energy production $\left(\mathrm{MWh}_{\mathrm{th}}\right)$ in suitable India locations Image by Billy Roberts

\subsection{Technical Potential}

Within $250 \mathrm{~m}$ of existing coal plants throughout India, the upper bound of technical potential is 5,207 $\mathrm{GWh}_{\text {th }}$, based on 25-MW th CSP SFs. The cumulative potential decreases to 5,038 $\mathrm{GWh}_{\text {th }}$ at the $100-\mathrm{MW}_{\text {th }} \mathrm{SF}$. Extending to $1,000 \mathrm{~m}$ from existing coal plants, the technical potential increases nearly twentyfold to 102,555 and $101,929 \mathrm{GWh}_{\text {th }}$ for the $25-\mathrm{MW}_{\text {th }}$ and $100-\mathrm{MW}_{\text {th }} \mathrm{SFs}$, respectively.

Note that, as shown in Table 2, as the installed CSP capacity within a given proximity from a coal plant increases, contiguous land area requirements increase, rendering the area less suitable 
overall. For example, at 1,000 m from existing coal plants, $392.9 \mathrm{~km}^{2}$ across India is suitable for CSP development at the $25-\mathrm{MW}_{\text {th }}$ capacity, whereas $2.4 \mathrm{~km}^{2}$ less land is available for hybridization at the 100-MW th capacity. CSP SFs larger than $100 \mathrm{MW}_{\text {th }}$ will linearly follow similar trends in declining resource availability. Also, it is worth noting that actual production should also be expected to be less than the reported technical potential, given that heat loss along transport from generation site to end use is not included in calculations.

Table 2. Technical Potential and Suitable Land Area by Coal Plant Proximity and CSP Project Size

\begin{tabular}{|c|c|c|c|c|c|c|}
\hline \multirow[b]{2}{*}{$\begin{array}{l}\text { CSP } \\
\text { Capacity }\end{array}$} & \multicolumn{2}{|c|}{$<250 \mathrm{~m}$ to Coal Plant } & \multicolumn{2}{|c|}{$<500 \mathrm{~m}$ to Coal Plant } & \multicolumn{2}{|c|}{$<1,000 \mathrm{~m}$ to Coal Plant } \\
\hline & $\begin{array}{l}\text { Total } \\
\text { Suitable } \\
\text { Land }\left(\mathrm{km}^{2}\right)\end{array}$ & $\begin{array}{l}\text { Total } \\
\text { Annual } \\
\text { GWh }_{\text {th }}\end{array}$ & $\begin{array}{l}\text { Total } \\
\text { Suitable } \\
\text { Land }\left(\mathrm{km}^{2}\right)\end{array}$ & $\begin{array}{l}\text { Total } \\
\text { Annual } \\
\text { GWh }_{\text {th }}\end{array}$ & $\begin{array}{l}\text { Total } \\
\text { Suitable } \\
\text { Land }\left(\mathrm{km}^{2}\right)\end{array}$ & $\begin{array}{l}\text { Total } \\
\text { Annual } \\
\text { GWh }_{\text {th }}\end{array}$ \\
\hline $25 \mathrm{MW}_{\text {th }}$ & 20.0 & 5,207 & 91.5 & 23,886 & 392.9 & 102,555 \\
\hline $50 \mathrm{MW}_{\text {th }}$ & 19.7 & 5,146 & 91.2 & 23,791 & 392.2 & 102,366 \\
\hline $100 \mathrm{MW}_{\text {th }}$ & 19.3 & 5,038 & 90.5 & 23,621 & 390.5 & 101,929 \\
\hline
\end{tabular}

At the site level, coal plants generally face significant technical constraints and are not situated to take advantage of the most concentrated DNI in India. Within 1,000 $\mathrm{m}$ of coal plants and assuming $25 \mathrm{MW}_{\text {th }}$ contiguous land use restrictions, the average capacity factor over suitable land is relatively low at $21.1 \%$ (23\% maximum). Even at this low capacity factor, each coal plant on average can utilize a $43-\mathrm{MW}$ th $\mathrm{SF}$ and could receive up to $81 \mathrm{GWh}_{\text {th }}$ in annual thermal energy production, assuming a 1,000-m land area proximity (See Appendix C for other coal plant proximities). When considering just coal plants with access to suitable land within 1,000 m $(\mathrm{n}=702)$, the average CSP capacity is closer to $80 \mathrm{MW}_{\text {th }}$, and the average thermal energy output increases to $146 \mathrm{GWh}_{\text {th. }}$. Note these statistics are also calculated before overlapping coal plant footprints are taken into consideration, so while coal plants can share CSP generation resources, actual land area and energy output strictly on a per-plant basis will be lower.

\subsubsection{State-Level Trends}

State generation statistics, summarized in Appendix C, reveal that Chhattisgarh is a leading state for further consideration regarding CSP-coal hybridization. On average, within 1,000 m of existing coal plants, each site is expected to have access to $0.53 \mathrm{~km}^{2}$ of suitable land that could produce $134 \mathrm{GWh}_{\text {th }}$ annually. These figures are well above the Indian average site land availability of $0.33 \mathrm{~km}^{2}$ and energy yield of $87 \mathrm{GWh}_{\text {th. }}$ Similar trends hold across all permutations of modeled system sizes and distance thresholds. Moreover, at all distances from existing coal plants modeled, Chhattisgarh supports greater thermal energy technical potential than any other state, accounting for nearly one-fifth of national energy thermal generation potential.

Technical potential in Chhattisgarh results from the state's abundant suitable land and higher number of coal plants $(n=139)$ than any other. Sites in this state receive only modest solar resource, and CSP-coal hybridization SFs in this region would operate at low capacity factors of approximately $20.8 \%$. The average capacity of coal plants in this area is in line with the national average of $366 \mathrm{MW}_{\mathrm{e}}$, and further economic analyses are necessary to validate the financial viability and optimal capacity of new CSP projects for hybridization in this state. 
While containing fewer coal plants than Chhattisgarh, similar productivity and land availability trends exist in Andhra Pradesh, Karnataka, and Rajasthan. Slightly elevated average capacity factors, which exceed $21.5 \%$ in Karnataka and Rajasthan, may help to make CSP-coal hybridization projects in these states more financially viable.

Notably, Tamil Nadu is also promising for CSP-coal hybridization; on average, $0.48 \mathrm{~km}^{2}$ of suitable land is available within 1,000 m of existing coal plants, and average SF capacity factors exceed $22 \%$. The resulting average SF thermal generation of $129 \mathrm{GWh}_{\text {th }}$ is per coal site per year in Tamil Nadu, which is nearly one and a half times the Indian national average of $87 \mathrm{GWh}_{\text {th. }} \mathrm{A}$ high number of existing coal plants near land estimated to support high average SF capacity factors render Tamil Nadu the state with the second most abundant technical potential. In fact, the site with the greatest SF capacity factor (23\%) is in Tamil Nadu near an operational coal plant with an operational capacity of up to $63 \mathrm{MW}$. Moreover, two larger coal plants near land that supports high-capacity factor SFs are planned in Tamil Nadu but not yet operational, as of data collection (KAPSARC 2018). Generally, the coal plants present in Tamil Nadu have nameplate capacities about $20 \mathrm{MW}_{\mathrm{e}}$ below average $\left(366 \mathrm{MW}_{\mathrm{e}}\right)$, suggesting that CSP installations could be used to offset a greater proportion of their total load.

Our results also illustrate that the quality solar resource does not vary so dramatically as to notably offset siting constraint limitations. CSP capacity factors in Gujarat, for example, are expected to be approximately $22 \%$ proximate to coal plants in this state, the second highest of any state. Still, with only $0.35 \mathrm{~km}^{2}$ of land suitable for development per site on average in this state, the average amount of energy available to each coal plant is moderate as well.

It is worth mentioning that, even if state-level trends do not indicate exceptional resource, CSPcoal hybridization may be economically viable. The first 15-MW th CSP plant to be hybridized with coal, for example, is in Uttar Pradesh, where land availability and solar resource are below average. This illustrative point alludes to the opportunity for even projects smaller than proposed in this paper to provide value in coal plant operations. It also suggests localized economic analyses will be critical in anticipating CSP-coal hybridization deployment possibilities. 


\section{Discussion}

This analysis suggests that, despite generally low solar resource and high likelihood of land use conflicts, CSP-coal hybridization may be able to account for $10 \%-20 \%$ of average coal plant capacity. In some states, CSP SF capacities may approach $100 \mathrm{MW}_{\text {th }}$, yet the average capacity addition is expected to be closer to $40 \mathrm{MW}_{\text {th. }}$. Existing coal plants typically have less than $20 \%$ of the land area within 1,000 $\mathrm{m}$ available for CSP SF development and this land is generally at the low end of suitable DNI intensity. The only CSP-coal hybridization project in India thus far (Dadri in Uttar Pradesh) is in a region with below-average resource and high rates of land-based constraints, suggesting these constraints may limit the size of deployments but not inhibit them entirely. It is worth noting that the $15-\mathrm{MW}_{\text {th }} \mathrm{SF}$ is smaller than the $25-\mathrm{MW}_{\text {th }}$ siting exclusion used in this study, and would not directly be highlighted as a potential opportunity until further refinement of the methodology occurs. Importantly, as in the case of the CSP-coal hybridization at Dadri, where the hybridization was found economically viable, future economic analysis of CSP-coal hybridization must be inclusive of local fees, coal costs, and incentives. Relative cost of current and alternative heat sources (e.g., biomass hybridization) must be considered on a siteby-site basis to assess the financial feasibility of widespread CSP hybridization in India.

This type of technical analysis can be improved with more refined time-series data on solar resource, system lags, and typical coal plant operations, to ensure CSP can deliver heat when needed. The inclusion of thermal heat loss along transport to the end-use location will also help refine these estimates. Moreover, the size and location of land parcels and additional CSP exclusions are likely to play a critical role in project viability at the site level. While CSP hybridization projects are amenable to some degree of fragmentation and siting reconfiguration to adjust to noncontiguous lots of varying shapes and sizes, such factors are likely to add to redundancies, efficiency losses, and additional system costs that reduce viability.

Future research will also need to consider integrated TES, where, for example, six hours of storage alone is estimated to effectively double the capacity factor range (IRENA 2012). Given that CSP production varies according to time of day, seasonal weather patterns, and meteorological conditions, storage of some kind will likely be needed to address the needs of coal plants, which typically provide schedulable baseload power. Storage systems are likely to impose additional land suitability constraints, and knowledge of temporal and spatial variability in coal plant dispatch patterns will help inform calculations of storage system size, costs, and design parameters.

Overall, ensuring the timing of CSP production meets the needs of coal plants is a topic for further research. Innovative procedures for coal plant operation and fuel supply chain organization (i.e., preheating and coal-drying) may help make effective use of variable solar resources. Understanding coal fuel type and origin, plant capacity, and the degree to which a plant typically has excess capacity will refine analysis of where and when CSP-coal hybridization will be effective as a peak power output reduction measure or to extend plant capacity. 


\section{Conclusions}

This report provides a preliminary estimate of the resource potential and technical thermal energy yield from parabolic trough technology without storage in areas adjacent to coal power plants in India. This paper's methodology employs GIS solar resource and land constraint characterizations to filter and anticipate the performance of suitable areas for development. The procedure is extensible to other CSP technologies (e.g., LF and power tower) and additional development constraints. Further methodological improvements will seek to capture the inherent temporal variability in both CSP production and coal plant dispatch, as well as the capacity for and value of thermal storage. Spatial variability in local incentives and integration costs are also likely to advantage CSP-coal hybridization beyond what is illustrated in this study.

Moreover, while the methodology has focused on assessing the CSP thermal potential for DNI conditions greater than $4.0 \mathrm{kWh} / \mathrm{m}^{2} /$ day, it is possible that coal power plants (e.g., the Dadri site) could benefit from SFs at less than $4.0 \mathrm{kWh} / \mathrm{m}^{2} /$ day based on local conditions (e.g., high price of coal, difficulty of coal transportation, or use of coal with lower heat rates). Financial modeling inclusive of metrics, such as the levelized cost of heat, will add to understanding the potential for CSP-coal hybridization in India.

While India receives 13,780 TWh each day in DNI, the average national capacity factor SFs of $16 \%$ suggests that CSP-even for hybridization in the country-will typically operate at the low end of financial viability. Still, within $1,000 \mathrm{~m}$ of coal plants in India, there is estimated to be nearly $103,000 \mathrm{GWh}_{\text {th }}$ of thermal energy potential from the development of 25-MW $\mathrm{MWSP}_{\text {th }}$ CSF, and the average coal plant could be augmented with a SF of $43 \mathrm{MW}_{\text {th }}$ that produces more than 80 $\mathrm{GWh}_{\text {th }}$ annually. Accordingly, at an average coal plant power capacity of $366 \mathrm{MW}_{\mathrm{e}}$, CSP will be best suited to applications that constitute a low proportion of total plant or turbine capacity, or those that improve efficiency in the fuel supply chain. In particular, Chhattisgarh, Andhra Pradesh, Karnataka, Rajasthan, and Tamil Nadu emerge as states where the prevalence of coal plants, suitable land, and abundant resource create conditions most supportive of CSP-coal hybridization.

Further work will seek to refine the suitability of the developed methodology at the substate and site level in India and model financial viability according to CSP integration strategies (e.g., using DSG or some type of heat input to the coal power plant, feedwater preheat, cold line reheat, coal drying). Results from such efforts will help clarify the role that CSP has to play among a suite of clean energy solutions in India and abroad.

This preliminary study suggests CSP-coal hybridization may play a supporting role in India's developing energy system. The topic of CSP-coal hybridization and use of CSP is an area of considerable interest in India (CSP Focus 2018), and the methodology developed could also be adapted for other areas of the world, such as the United States. 


\section{References}

Bijarniya, Jay Prakash, K Sudhakar, and Prashant Baredar. 2016. “Concentrated Solar Power Technology in India: A Review." Renewable and Sustainable Energy Reviews 63 (May 2016): 593-603.

Choudhury, Nilima. "India Unveils Plans for Massive Concentrated Solar Power." Climate Home News, July 18, 2013. http://www.climatechangenews.com/2013/07/18/india-unveils-plansfor-massive-concentrated-solar-power/.

CSP Focus. 2018. "Coal India, NLC Sign MoU for Concentrated Solar Power.” October 8, 2018. http://cspfocus.cn/en/market/detail_1008.htm.

CSP Today. "India Picks Fresnel for Its First CSP-Coal Plant; New US Land Rules Lower Solar Costs.” New Energy Update: CSP. November 15, 2016.

http://analysis.newenergyupdate.com/csp-today/markets/india-picks-fresnel-its-first-csp-coalplant-new-us-land-rules-lower-solar-costs.

Deign, Jason. "Germany Looks to Put Thermal Storage into Coal Plants." Green Tech Media. March 18, 2019. https://www.greentechmedia.com/articles/read/germany-thermal-storage-intocoal-plants.

Deshmukh, Sandip S., Onkareshwar Mishra, Vatsal Agrawal, and Khalid Anwar. "Hybrid-CSP in India: Technological and Economic Aspects." International Journal of Renewable Energy Research (IJRER) 9 (1): 137-46.

Economic Times of India, "India Imported Coal Worth over Rs 1 Lakh Crore in FY'17," The Economic Times, July 20, 2017, https://economictimes.indiatimes.com/industry/indlgoods/svs/metals-mining/india-imported-coal-worth-over-rs-1-lakh-crore-infy17/articleshow/59682781.cms.

EIA (U.S. Energy Information Administration). "India Is Increasingly Dependent on Imported Fossil Fuels as Demand Continues to Rise.” August 14, 2014.

https://www.eia.gov/todayinenergy/detail.php?id=17551.

GADM (Database of Global Administrative Areas). "GADM Maps and Data." Global Administrative Areas. Last modified 2018. http://gadm.org/.

Geofabrik. “OpenStreetMap Data Extracts; India.” Last modified 2018. http://download.geofabrik.de/asia/india.html.

Hakkarainen, Elina, Suvi Suojanen, Matti Tähtinen, Toni Pikkarainen, Antton Tapani, Teemu Sihvonen, and Markus Hurskainen. Concentrated Solar Power and Circulating Fluidized Bed Power Plant Hybrids. T296. Finland: VTT (Technical Research Center of Finland). 2017. http://www.vtt.fi/inf/pdf/technology/2017/T296.pdf. 
Hasem, Heba. "Fresnel Developer Builds India Supply Base to Serve 1.7 GW CSP-Coal Market." New Energy Update: CSP. January 25, 2017. http://analysis.newenergyupdate.com/csptoday/emerging-markets-csp-markets-technology/fresnel-developer-builds-india-supply-baseserve? utm campaign $=\mathrm{NEP}+\mathrm{CSP}+25 \mathrm{JAN} 17+\mathrm{Newsletter \& utm} \mathrm{medium}=$ email\&utm source $=\mathrm{Elo}$ qua\&elqTrackId $=$ aa0d69bc903d4fa387670f3f7173c3cd\&elq $=$ aa665568026b4926861811881c57 $\underline{0122 \& \text { elqaid }=25058 \& \text { elqat }=1 \text { \&elqCampaignId }=11490 .}$.

IRENA (International Renewable Energy Agency). Renewable Energy Technologies: Cost Analysis Series-Concentrating Solar Power. Volume 1: Power Sector (Issue 2/5). https://www.irena.org/documentdownloads/publications/re technologies_cost analysis-csp.pdf.

KAPSARC (King Abdullah Petroleum Studies and Research Center). "India Coal Power Plants Database." Last modified October 21, 2015. https://datasource.kapsarc.org/explore/dataset/coalpower-plants$\underline{\text { database_india_final/?disjunctive.coal_type\&disjunctive.state\&disjunctive.plant_name. }}$

Kulichenko, Nataliya, Ashish Khanna, Chandrasekeren Subramaniam, Mani Khurana, Kanv Garg, and Ruchi Soni. Development of Local Supply Chain: The Missing Link for Concentrated Solar Power Projects in India. The World Bank: ESMAP (Energy Sector Management Assistance Program). https://www.esmap.org/sites/esmap.org/files/DocumentLibrary/ESMAP\%20WB_Development $\% 20$ of $\% 20$ Local $\% 20$ CSP $\% 20$ Supply $\% 20$ Chain $\% 20 \mathrm{in} \% 20$ India Full_Optimized.pdf.

Kurup, Parthiv, and Craig S. Turchi. Initial Investigation into the Potential of CSP Industrial Process Heat for the Southwest United States. NREL/TP-6A20-64709. Golden, CO: NREL (National Renewable Energy Laboratory). November 2015. http://www.nrel.gov/docs/fy16osti/64709.pdf.

Lopez, Anthony, Billy Roberts, Donna Heimiller, Nate Blair, and Gian Porro. U.S. Renewable Energy Technical Potentials: A GIS-Based Analysis. NREL/TP-6A20-51946. Golden, CO: NREL. July 2012. https://www.nrel.gov/docs/fy12osti/51946.pdf.

Mehos, Mark, Craig Turchi, Jennie Jorgenson, Paul Denholm, Clifford Ho, and Kenneth Armijo. On the Path to SunShot: Advancing Concentrating Solar Power Technology, Performance, and Dispatchability. NREL/TP-5500-65688. Golden, CO: NREL. May 2016. https://www.nrel.gov/docs/fy16osti/65688.pdf.

NASA. "Decadal Land Use and Land Cover Classifications across India, 1985, 1995, 2005." Last modified September 1, 2016. https://daac.ornl.gov/VEGETATION/guides/Decadal_LULC_India.html.

NREL. "Advancing the Science of Solar Data." National Solar Radiation Database (NSRDB). Accessed June 13, 2019. https://nsrdb.nrel.gov/.

NREL, SolarPACES (Solar Power and Chemical Energy Systems). "Concentrating Solar Power Projects." 2017. https://www.nrel.gov/csp/solarpaces/. 
NTPC. "Solar Thermal Hybrid Plant at Dadri." May 19, 2016. http://www.eqmagpro.com/wpcontent/uploads/2017/06/1_NTPC 5_SolarThermalHybridPlant_Haldar.pdf.

Palchak, David, Jaquelin Cochran, Ranjit Deshmukh, Ali Ehlen, Sushil Kumar Soonee, S. R. Narasimhan, Mohit Joshi, et al. Greening the Grid: Pathways to Integrate 175 Gigawatts of Renewable Energy into India's Electric Grid, Vol. 1. National Study. NREL/TP-6A20-68530. Berkeley, CA: Lawrence Berkeley National Lab (LBNL); Golden, CO: NREL; New Delhi: Power System Operation Corporation (POSOCO); Washington, DC: US Agency for International Development (USAID). https://doi.org/10.2172/1393627.

Penney, Kate, and Ian Cronshaw. "Coal in India 2015.” June, 2015. Australian GovernmentDepartment of Industry and Science. https://www.industry.gov.au/sites/g/files/net3906/f/June \%202018/document/pdf/coal-inindia.pdf.

ProtectedPlanet. "World Database on Protected Areas." Accessed June 13, 2019. https://www.protectedplanet.net/c/world-database-on-protected-areas.

RWE Power AG. "Groundbreaking pilot project: A heat storage power plant is being built on the Rheinische River (translated)." Wegweisendes Pilotprojekt: Im Rheinischen Revier entsteht ein Wärmespeicherkraftwerk. March 15, 2019. https://news.rwe.com/wegweisendes-pilotprojekt-imrheinischen-revier-entsteht-ein-warmespeicherkraftwerk/.

Schuknecht, Nate, Pamela A. Kulbeik, and Deven M. O'Rourke. "The Economic Potential and Technical Feasibility of Hybridizing Coal Power Plants with Parabolic Troughs." Power Energy 2017. North Carolina: ASME (American Society of Mechanical Engineers).

Tongia, Rahul, and Samantha Gross. Coal in India: Adjusting to Transition. Brookings. March 2019. https://www.brookings.edu/wpcontent/uploads/2019/03/Tongia and Gross 2019 Coal In India Adjusting To Transition.pdf

Turchi, Craig, Nicholas Langle, Robin Bedilion, and Cara Libby. Solar-Augment Potential of U.S. Fossil-Fired Power Plants. NREL/TP-5500-50597. Golden, CO: NREL. http://www.nrel.gov/docs/fy11 osti/50597.pdf.

USGS. 1993. "USGS EROS Archive - Digital Elevation - Global 30 Arc-Second Elevation (GTOPO30)." https://www.usgs.gov/centers/eros/science/usgs-eros-archive-digital-elevationglobal-30-arc-second-elevation-gtopo30?qt-science center_objects $=0$ \#qtscience_center_objects.

X-Rates. "Historic Exchange Rates (Indian Rupee) on May 19th 2016." Last modified May 19, 2016. https://www.X-rates.com/historical/?from=INR\&amount=690000000\&date=2016-05-19. 


\section{Appendix A. Land Use and Cover Classification Exclusions}

Table A- 1 describes the land classifications from NASA's Decadal Land Use and Land Cover Classification for 2005 and whether each was excluded in this analysis.

Table A- 1. Land Use and Cover Classification Exclusions 2005

\begin{tabular}{ll}
\hline Classification & Suitable for CSP \\
\hline Deciduous Broadleaf Forest & False \\
\hline Cropland & True \\
\hline Built-up Land & False \\
\hline Mixed Forest & True \\
\hline Shrubland & True \\
\hline Barren Land & True \\
\hline Fallow Land & True \\
\hline Wasteland & True \\
\hline Water Bodies & False \\
\hline Plantations & True \\
\hline Aquaculture & False \\
\hline Mangrove Forest & False \\
\hline Salt Pan & True \\
\hline Grassland & True \\
\hline Evergreen Broadleaf Forest & False \\
\hline Deciduous Needleleaf Forest & False \\
\hline Permanent Wetlands & False \\
\hline Snow and Ice & False \\
\hline Evergreen Needleleaf Forest & False \\
\hline
\end{tabular}




\section{Appendix B. State Resource Potential and Exclusion Statistics}

Table B- 1 quantifies resource potential and excluded land area across states in India.

Table B-1. State Resource Potential and Exclusion Statistics

\begin{tabular}{|c|c|c|c|c|c|c|c|}
\hline Region & State & $\begin{array}{l}\text { Area } \\
\left(\mathbf{k m}^{2}\right)\end{array}$ & $\begin{array}{l}\text { DNI, } \\
\text { kWh/ } \\
\text { m²- }^{2} \\
\text { day }\end{array}$ & $\begin{array}{l}\text { Capaci } \\
\text { ty } \\
\text { Factor } \\
(\%)\end{array}$ & $\begin{array}{l}\text { Annual } \\
\text { Generation, } \\
\text { GWh }\end{array}$ & $\begin{array}{l}\text { Number of } \\
\text { Coal Plants } \\
\text { (Avg. } \\
\text { Capacity) }\end{array}$ & $\begin{array}{l}\text { Total } \\
\text { Excluded } \\
\text { Land } \\
\text { Area }\end{array}$ \\
\hline Northern & Jammu and Kashmir & 105660 & 5.29 & 21.00 & 27080 & 1 & $12 \%$ \\
\hline Western & Daman and Diu & 80 & 4.81 & 21.97 & 20 & 1 & $27 \%$ \\
\hline Southern & Lakshadweep & 30 & 4.79 & 21.98 & 10 & 1 & $0 \%$ \\
\hline Southern & Tamil Nadu & 130280 & 4.79 & 21.55 & 34250 & 112 (346 MW) & $68 \%$ \\
\hline Southern & Karnataka & 191380 & 4.77 & 21.85 & 51030 & 44 (397 MW) & $66 \%$ \\
\hline Southern & Puducherry & 550 & 4.75 & 21.87 & 150 & 1 & $56 \%$ \\
\hline Western & Gujarat & 185720 & 4.73 & 21.82 & 49450 & 92 (376 MW) & $66 \%$ \\
\hline Western & Rajasthan & 341900 & 4.73 & 21.60 & 90100 & 76 (258 MW) & $68 \%$ \\
\hline Northern & Uttarakhand & 53810 & 4.72 & 21.34 & 14010 & 1 & $14 \%$ \\
\hline Northern & Himachal Pradesh & 55600 & 4.68 & 19.58 & 13290 & 1 & $13 \%$ \\
\hline Western & Maharashtra & 307340 & 4.60 & 21.49 & 80610 & $125(347 \mathrm{MW})$ & $66 \%$ \\
\hline Western & Dadra and Nagar Haveli & 490 & 4.52 & 21.30 & 130 & 1 & $30 \%$ \\
\hline Western & Madhya Pradesh & 308050 & 4.49 & 21.04 & 79090 & 93 (425 MW) & $52 \%$ \\
\hline Southern & Andhra Pradesh & 160050 & 4.49 & 21.16 & 41320 & 61 (565 MW) & $59 \%$ \\
\hline Southern & Telangana & 114710 & 4.49 & 21.20 & 29680 & 46 (393 MW) & $63 \%$ \\
\hline Eastern & Chhattisgarh & 135430 & 4.45 & 21.11 & 34880 & 139 (369 MW) & $37 \%$ \\
\hline Southern & Goa & 3700 & 4.44 & 21.09 & 950 & 1 & $20 \%$ \\
\hline Eastern & Mizoram & 21140 & 4.35 & 20.79 & 5360 & 1 & $4 \%$ \\
\hline Southern & Kerala & 37700 & 4.27 & 17.75 & 8170 & 1 & $33 \%$ \\
\hline Eastern & Odisha & 155640 & 4.21 & 17.37 & 32990 & $122(369 \mathrm{MW})$ & $45 \%$ \\
\hline Eastern & Andaman and Nicobar & 7610 & 4.16 & 18.24 & 1690 & 1 & $3 \%$ \\
\hline Eastern & Jharkhand & 80040 & 4.16 & 15.64 & 15270 & 67 (323 MW) & $41 \%$ \\
\hline
\end{tabular}




\begin{tabular}{|c|c|c|c|c|c|c|c|}
\hline Region & State & $\begin{array}{l}\text { Area } \\
\left(\mathbf{k m}^{2}\right)\end{array}$ & $\begin{array}{l}\text { DNI, } \\
\text { kWh/ } \\
\text { m²- }^{2} \\
\text { day }\end{array}$ & $\begin{array}{l}\text { Capaci } \\
\text { ty } \\
\text { Factor } \\
(\%)\end{array}$ & $\begin{array}{l}\text { Annual } \\
\text { Generation, } \\
\text { GWh }\end{array}$ & $\begin{array}{l}\text { Number of } \\
\text { Coal Plants } \\
\text { (Avg. } \\
\text { Capacity) }\end{array}$ & $\begin{array}{l}\text { Total } \\
\text { Excluded } \\
\text { Land } \\
\text { Area }\end{array}$ \\
\hline Northern & Chandigarh & 120 & 4.10 & 20.25 & 30 & 1 & $10 \%$ \\
\hline Eastern & Manipur & 22320 & 3.99 & 10.98 & 2990 & 1 & $7 \%$ \\
\hline Northern & Haryana & 44020 & 3.92 & 5.36 & 2880 & 17 (352 MW) & $90 \%$ \\
\hline Northern & Uttar Pradesh & 240750 & 3.88 & 4.26 & 12520 & 108 (344 MW) & $82 \%$ \\
\hline Eastern & Tripura & 10450 & 3.85 & 1.86 & 240 & 1 & $21 \%$ \\
\hline Northern & NCT of Delhi & 1500 & 3.79 & 0.00 & 0 & 7 (120 MW) & $22 \%$ \\
\hline Northern & Punjab & 50230 & 3.79 & 0.67 & 410 & 29 (351 MW) & $86 \%$ \\
\hline Eastern & Bihar & 94230 & 3.72 & 1.26 & 1450 & 39 (470 MW) & $79 \%$ \\
\hline Eastern & West Bengal & 85230 & 3.67 & 1.24 & 1290 & 76 (299 MW) & $63 \%$ \\
\hline Eastern & Nagaland & 16600 & 3.60 & 0.69 & 140 & 1 & $10 \%$ \\
\hline Eastern & Assam & 78450 & 3.49 & 0.77 & 730 & 5 (350 MW) & $44 \%$ \\
\hline Eastern & Sikkim & 7080 & 3.46 & 5.45 & 470 & 1 & $4 \%$ \\
\hline Eastern & Meghalaya & 22430 & 3.40 & 0.00 & 0 & 5 (144 MW) & $11 \%$ \\
\hline \multirow[t]{2}{*}{ Eastern } & Arunachal Pradesh & 82000 & 2.58 & 0.14 & 140 & 1 & $4 \%$ \\
\hline & TOTAL & 3154200 & 4.37 & 0.16 & 13,785 & $\begin{array}{l}1,265 \text { (366 } \\
\text { MW) }\end{array}$ & $44 \%$ \\
\hline
\end{tabular}




\section{Appendix C. Average Site Technical Potential, Land Suitability, and Capacity Factors by State}

Table C- 1 quantifies average site technical potential, available land area, and capacity factor for states in India that have sites with some technical potential.

Table C- 1. Average Technical Potential, Land Suitability, and Capacity Factors by State

\begin{tabular}{|c|c|c|c|c|c|c|c|}
\hline \multirow[b]{2}{*}{$\begin{array}{l}\text { State / CSP } \\
\text { Capacity MW }\end{array}$} & \multicolumn{3}{|c|}{$\begin{array}{l}\text { Average Annual Energy } \\
\text { Production Per Site }\end{array}$} & \multicolumn{4}{|c|}{$\begin{array}{l}\text { Average Suitable Land Area } \\
\text { Per Site }\end{array}$} \\
\hline & $\begin{array}{l}250 \mathrm{~m} \\
\mathrm{GWh}\end{array}$ & $\begin{array}{c}500 \mathrm{~m} \\
\text { GWh }\end{array}$ & $\begin{array}{l}1,000 \mathrm{~m} \\
\mathrm{GWh}\end{array}$ & $\begin{array}{l}250 \mathrm{~m} \\
\mathrm{~km}^{2}\end{array}$ & $\begin{array}{l}500 \mathrm{~m} \\
\mathrm{~km}^{2}\end{array}$ & $\begin{array}{l}1,000 \mathrm{~m} \\
\mathrm{~km}^{2}\end{array}$ & $\begin{array}{l}\text { Avg. } \\
\text { Capacity } \\
\text { Factor }\end{array}$ \\
\hline \multicolumn{8}{|c|}{ Andhra Pradesh } \\
\hline 25 & 7 & 35 & 150 & 0.03 & 0.14 & 0.59 & $21.0 \%$ \\
\hline 50 & 7 & 35 & 149 & 0.03 & 0.14 & 0.58 & $21.0 \%$ \\
\hline 100 & 7 & 35 & 149 & 0.03 & 0.13 & 0.58 & $21.0 \%$ \\
\hline \multicolumn{8}{|l|}{ Chhattisgarh } \\
\hline 25 & 7 & 31 & 134 & 0.03 & 0.12 & 0.53 & $20.8 \%$ \\
\hline 50 & 7 & 31 & 133 & 0.03 & 0.12 & 0.53 & $20.8 \%$ \\
\hline 100 & 7 & 31 & 133 & 0.03 & 0.12 & 0.53 & $20.8 \%$ \\
\hline \multicolumn{8}{|l|}{ Gujarat } \\
\hline 25 & 5 & 23 & 93 & 0.02 & 0.09 & 0.35 & $22.0 \%$ \\
\hline 50 & 5 & 23 & 93 & 0.02 & 0.09 & 0.35 & $22.0 \%$ \\
\hline 100 & 5 & 23 & 93 & 0.02 & 0.09 & 0.35 & $22.0 \%$ \\
\hline \multicolumn{8}{|l|}{ Haryana } \\
\hline 25 & 0 & 0 & 24 & 0.00 & 0.00 & 0.10 & $20.2 \%$ \\
\hline 50 & 0 & 0 & 23 & 0.00 & 0.00 & 0.09 & $20.2 \%$ \\
\hline 100 & 0 & 0 & 23 & 0.00 & 0.00 & 0.09 & $20.2 \%$ \\
\hline \multicolumn{8}{|l|}{ Jharkhand } \\
\hline 25 & 3 & 12 & 57 & 0.01 & 0.05 & 0.23 & $19.9 \%$ \\
\hline 50 & 3 & 12 & 56 & 0.01 & 0.05 & 0.23 & $19.9 \%$ \\
\hline 100 & 3 & 12 & 56 & 0.01 & 0.05 & 0.23 & $19.9 \%$ \\
\hline \multicolumn{8}{|l|}{ Karnataka } \\
\hline 25 & 7 & 33 & 126 & 0.03 & 0.12 & 0.48 & $21.6 \%$ \\
\hline 50 & 7 & 33 & 126 & 0.03 & 0.12 & 0.48 & $21.6 \%$ \\
\hline 100 & 7 & 33 & 125 & 0.03 & 0.12 & 0.48 & $21.6 \%$ \\
\hline \multicolumn{8}{|c|}{ Madhya Pradesh } \\
\hline 25 & 4 & 16 & 65 & 0.01 & 0.06 & 0.26 & $20.9 \%$ \\
\hline 50 & 4 & 16 & 65 & 0.01 & 0.06 & 0.26 & $20.9 \%$ \\
\hline 100 & 4 & 15 & 65 & 0.01 & 0.06 & 0.26 & $20.9 \%$ \\
\hline \multicolumn{8}{|l|}{ Maharashtra } \\
\hline 25 & 4 & 20 & 84 & 0.02 & 0.08 & 0.32 & $21.3 \%$ \\
\hline 50 & 4 & 20 & 84 & 0.02 & 0.08 & 0.32 & $21.3 \%$ \\
\hline
\end{tabular}




\begin{tabular}{|c|c|c|c|c|c|c|c|}
\hline \multirow[b]{2}{*}{$\begin{array}{l}\text { State / CSP } \\
\text { Capacity MW }\end{array}$} & \multicolumn{3}{|c|}{$\begin{array}{l}\text { Average Annual Energy } \\
\text { Production Per Site }\end{array}$} & \multicolumn{4}{|c|}{$\begin{array}{l}\text { Average Suitable Land Area } \\
\text { Per Site }\end{array}$} \\
\hline & $\begin{array}{l}250 \mathrm{~m} \\
\mathrm{GWh}\end{array}$ & $\begin{array}{c}500 \mathrm{~m} \\
\text { GWh }\end{array}$ & $\begin{array}{l}1,000 \mathrm{~m} \\
\mathrm{GWh}\end{array}$ & $\begin{array}{l}250 \mathrm{~m} \\
\mathrm{~km}^{2}\end{array}$ & $\begin{array}{l}500 \mathrm{~m} \\
\mathrm{~km}^{2}\end{array}$ & $\begin{array}{l}1,000 \mathrm{~m} \\
\mathrm{~km}^{2}\end{array}$ & $\begin{array}{l}\text { Avg. } \\
\text { Capacity } \\
\text { Factor }\end{array}$ \\
\hline 100 & 4 & 19 & 83 & 0.02 & 0.08 & 0.32 & $21.3 \%$ \\
\hline \multicolumn{8}{|l|}{ Odisha } \\
\hline 25 & 4 & 18 & 79 & 0.01 & 0.07 & 0.33 & $19.9 \%$ \\
\hline 50 & 4 & 18 & 79 & 0.01 & 0.07 & 0.33 & $19.9 \%$ \\
\hline 100 & 3 & 18 & 78 & 0.01 & 0.07 & 0.32 & $19.9 \%$ \\
\hline \multicolumn{8}{|l|}{ Rajasthan } \\
\hline 25 & 6 & 29 & 123 & 0.02 & 0.11 & 0.46 & $21.8 \%$ \\
\hline 50 & 6 & 29 & 123 & 0.02 & 0.11 & 0.46 & $21.8 \%$ \\
\hline 100 & 6 & 29 & 122 & 0.02 & 0.11 & 0.46 & $21.8 \%$ \\
\hline \multicolumn{8}{|l|}{ Tamil Nadu } \\
\hline 25 & 6 & 27 & 129 & 0.02 & 0.10 & 0.48 & $22.1 \%$ \\
\hline 50 & 5 & 27 & 129 & 0.02 & 0.10 & 0.48 & $22.1 \%$ \\
\hline 100 & 5 & 27 & 129 & 0.02 & 0.10 & 0.48 & $22.1 \%$ \\
\hline \multicolumn{8}{|l|}{ Telangana } \\
\hline 25 & 6 & 26 & 103 & 0.02 & 0.10 & 0.41 & $20.7 \%$ \\
\hline 50 & 6 & 26 & 102 & 0.02 & 0.10 & 0.40 & \\
\hline 100 & 5 & 26 & 102 & 0.02 & 0.10 & 0.40 & \\
\hline \multicolumn{8}{|l|}{ Uttar Pradesh } \\
\hline 25 & 1 & 4 & 17 & 0.00 & 0.00 & 0.00 & $19.1 \%$ \\
\hline 50 & 1 & 4 & 17 & 0.00 & 0.00 & 0.00 & $19.1 \%$ \\
\hline 100 & 1 & 4 & 17 & 0.00 & 0.00 & 0.00 & $19.1 \%$ \\
\hline \multicolumn{8}{|l|}{ West Bengal } \\
\hline 25 & 0 & 0 & 0 & 0.00 & 0.00 & 0.00 & $8.2 \%$ \\
\hline 50 & 0 & 0 & 0 & 0.00 & 0.00 & 0.00 & $8.2 \%$ \\
\hline 100 & 0 & 0 & 0 & 0.00 & 0.00 & 0.00 & $8.2 \%$ \\
\hline \multicolumn{8}{|l|}{ TOTAL } \\
\hline 25 & 4 & 20 & 87 & 0.02 & 0.08 & 0.33 & $21.1 \%$ \\
\hline 50 & 4 & 20 & 87 & 0.02 & 0.08 & 0.33 & $20.1 \%$ \\
\hline 100 & 4 & 20 & 87 & 0.02 & 0.08 & 0.33 & $20.1 \%$ \\
\hline
\end{tabular}

